\title{
Controversies of the Anterolateral Complex of the Knee
}

Editors

FREDDIE H. FU

MARCIN KOWALCZUK

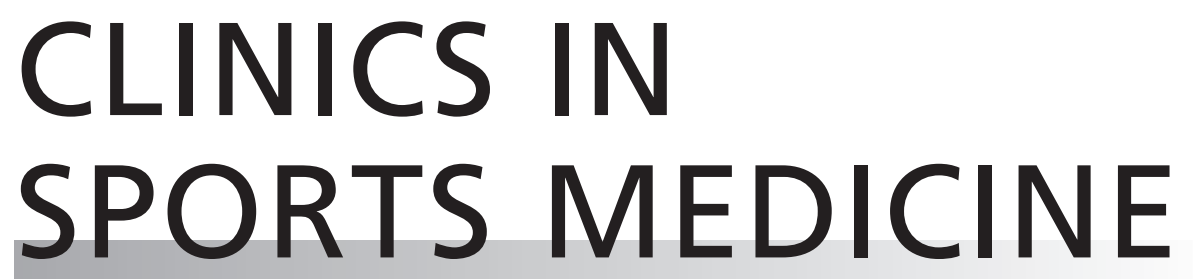

www.sportsmed.theclinics.com

Consulting Editor

MARK D. MILLER

January 2018 • Volume 37 • Number 1 